 \\ Journal of \\ Human, Earth, and Future
}

ISSN: 2785-2997

Vol. 2, No. 2, June, 2021

\section{Sensations of Air Temperature Variability and Mitigation Strategies in Urban Environments}

\author{
A. P. Sampson ${ }^{1 *}$, V. E. Weli ${ }^{1}{ }^{\oplus}$, M. O. Nwagbara ${ }^{1}$, O. S. Eludoyin ${ }^{1}{ }^{\infty}$ \\ ${ }^{l}$ Department of Geography and Environmental Management, University of Port Harcourt, Choba, Rivers State, Nigeria
}

Received 03 March 2021; Revised 18 May 2021; Accepted 23 May 2021; Published 01 June 2021

\begin{abstract}
This study examined sensations of air temperature variability and mitigation strategies in the Niger Delta, Nigeria, using cross-sectional and descriptive research designs. This study purposively selected the capital cities of the nine states in the study area, while the simple random sampling technique was used to select the study elements. The Taro Yamane (1967) formula was employed in determining the study sample size of 400 , which was apportioned to each of the cities based on proportional allocation with respect to the population of the cities, hence forming the basis for the distribution of the survey questionnaire. The results show that the majority were aware of the impacts of temperature and rated the temperature in the neighborhood as high, but were not aware of the comfort threshold of air temperature. The majority had never taken personal steps to mitigate high temperatures and, at the same time, were not satisfied with the level of temperature in their urban environment. Urban growth and rise in population, construction materials of urban surfaces, removal of trees/vegetation, manmade heat, air pollutants emission, congestion of buildings and time of season were found to stimulate high temperatures in the cities. Human discomfort, excessive heat, illness and diseases, soil aridity/lack of water in soil, poor air quality, increase in disease vectors, increase in energy demand and usage, and dehydration of the body and regular thirst for water were found to be impacts and problems associated with high temperatures. The prevailing strategies adopted to mitigate the impacts of high temperatures were only the use of electric fans $(63.50 \%)$ and the drinking of plenty of water $(92.50 \%)$. Therefore, the study recommends, among other things, that planting and preservation of trees should be encouraged, a mass awareness campaign on practices that exacerbate high temperatures should be sponsored by the authorities, and regulatory agencies should strictly control urban growth and be committed to the enforcement of environmental policies.
\end{abstract}

Keywords: Climate Change; Sensations; Air Temperature; Variability; Mitigation Strategies; Niger Delta.

\section{Introduction}

More than half of the world's population (55\%) and many of its socioeconomic activities are concentrated in cities, and this population is expected to grow to $68 \%$ by 2050 (United Nations, Department of Economic and Social Affairs, Population Division (UN DESA, 2014 and 2018) [1-3]. However, a significant portion of this population and economic activities are threatened by global climate change and extreme weather, including a significant amount of global greenhouse gas emissions produced by these concentrated urban-based residents and their undertakings [4]. The natural covering of the urban environment consisting of vegetation, bare soils, water bodies, wetlands and open spaces

* Corresponding author: adonisampson@yahoo.com

doi) http://dx.doi.org/10. 28991/HEF-2021-02-02-02

$>$ This is an open access article under the CC-BY license (https://creativecommons.org/licenses/by/4.0/).

(C) Authors retain all copyrights. 
are often been supplanted with features of various land use types like buildings, roads, pavements and other artificial structures made of different materials such as asphalt, metals and bricks, which in their rights can absorb heat in the day and thereafter release same at night; all together leading to rise in the surface temperature of the urban milieu and this in turn donates to the development of the Urban Heat Island (UHI) phenomenon [5-9].

The UHI is an indicator of warmer temperatures in urban environments as opposed to cooler temperatures in adjoining rural areas due to the increased temperature of the urban surface $[8,9]$. These scenarios experienced in urban environments are expected to get worse in time, given the fact that the world is still urbanising, unless conscious efforts and frantic commitments are made towards reordering the paradigm by all means disposable. Universally, air temperature (AT) or land surface temperature (LST) can be denoted as the temperature of the air as observed at between $1.2 \mathrm{~m}$ and $2 \mathrm{~m}$ above the ground surface [10, 11], which, according to Voogt \& Oke (1997) in Unger et al. (2009), is the overall surface temperature which cannot be determined straight-away or from a particular direction, but rather can be considered or assessed as an outcome of the radiation coming from the totality of surfaces, both from plane and plumb directions $[12,13]$.

The urban microclimate is impacted by various biophysical elements of the urban environment such as surface materials, city structure, introduction of heat, air pollution, disposition of precipitation and urban vegetation [14, 15], dense building developments, landuse changes and plenty of other human activities (Hong Kong Observatory, 2018) [16]. Studies have identified several other factors that influence temperature variability, such as seasonal variances in solar radiation [17]; anthropogenic emissions (Intergovernmental Panel on Climate Change, IPCC, 2018) [18]; weather conditions, latitude, time, topography, stability, wind, cloudiness, snow cover, artificial heat sources, and street geometry [19]; seasonal differences in rainfall and prolonged dry or wet seasons [58]; climate change [20]; land use change and urbanisation process [15, 21-27]; and thermal characteristics of the construction materials in the cities [28].

A close look at these variables reveals that urbanisation and its features, as well as man's quest for survival and comfort, are focal drivers of high air temperatures. Even in the face of supposed natural phenomena as advanced by Saadatabad \& Bidokhti (2011) [19], Feulner et al. (2013) [17], Ayanlade (2016) [5] and Igun (2017) [8], man's inherent proclivity to adjust and adapt to these phenomena with all his paraphernalia in the bid for his continuous wellbeing and sustenance makes him the fulcrum of air temperature variability.

The effects of climate-related risks such as high temperatures may be short-term, longer-term or irreversible, as in the case of the loss of some ecosystems, contingent on the proportion, peak and length of warming (IPCC, 2018) [18]. Nonetheless, some of the effects include: protracted hot season [14]; upsurge in energy demand, usage, and thus spending in addition to degrading the air quality via the emission of more heat from vehicles and air-conditioners intended to bring comfort [14, 29, 30]; reduced agricultural produce [14]; numerous health impacts including heat stress, heat cramps, heat exhaustion, heatstroke (Harmon, 2010 [31]; Canadian Centre for Occupational Health and Safety (CCOHS), 2019 [32]), hyperthermia and hypothermia, cardiovascular, kidney, and respiratory and Premature deaths [33].

However, high temperature can be mitigated by good legislations; tree planting; suitable zoning policies that will develop road networks and industries that will support efficient burning of fossil fuel; environmental awareness; compliance to development regulations [22]; conservation of the urban ecosystems and planning small, detached, and stretched cities which are better [34]; and provision of complementary urban amenities [8]. In addition, reorientation of citizens attitude and sincere commitment of the authorities to provide and strictly enforce planning regulations and instil friendly environmental practices and behaviours, especially in less developed and developing countries, will to a large extent complement any other mitigation actions.

Truly trustworthy datasets on trustworthy air temperature files are limited, just as the number of weather stations that produce time series recordings are limited, making them deficient in being representative of wider areas and thereby giving rise to the application of satellites $[10,11,35]$. The foregoing not only implies that there are numerous studies previously conducted in the general sphere of air temperature variability, but also that there is fundamentally meagre attention towards public perception of factors of urban air temperature variability. Whereas, what people feel, belief and how they behave build their culture which in turn reveals possible events in their environment, as well as where and how to track them and further actions to be taken on them [36, 37]; and for the aptitude of humans to competently handle and control the natural resources of the environment to increase, the opinions and sensations of the population of the related immediate environment necessarily have to be taken into consideration along with those of experts or administrators (UNESCO, 1977) [38]. It is against these backdrops that this study was undertaken to examine the perceived causes and impacts of high air temperature sensations and assess the strategies adopted by the urban residents to mitigation high air temperature in the capital cities of Niger Delta States. 


\section{Materials And Methods}

\subsection{Study Area}

This study was carried out in the Niger Delta Region (NDR) of Nigeria located between latitudes $4.15^{\circ} \mathrm{N}$ and $7.17^{\circ} \mathrm{N}$ and longitudes $5.05^{\circ} \mathrm{E}$ and $8.68^{\circ} \mathrm{E}$ at the southern belt of forest soils [39]. It comprises Abia, Akwa Ibom, Bayelsa, Cross Rivers, Delta, Edo, Imo, Ondo and Rivers States and collectively covers a land area of $112,110 \mathrm{~km}^{2}$, which is $12 \%$ of the total land area of Nigeria (NDDC, 2006) [40]. It falls within the tropical rainforest climate and a warm humid sea to land seasonal wind, characterising wet and dry seasons [41]. The mean annual rainfall is between $2000 \mathrm{~mm}$ to $4500 \mathrm{~mm}$ around the northern fringe to the coastal margin [42] and average temperature of $27^{\circ} \mathrm{C}$ along the coastal fringe to about $28^{\circ} \mathrm{C}$ in the interiors [42]. The soil is rich in vast alluvial basin consisting of medium to coarse unconsolidated sands, silt, clay, shale and peat which cut across its flat, low-lying swampy basin that is traversed by a solid web of winding rivers and creeks characterising a ridge and valley topography (NDDC 2006). The region is rich in flora and fauna which are spread in five major ecological zones, namely; mangrove swamp forest eco-zone, fresh water swamp forest eco-zone, tropical (lowland) rainforest zone, derived savannah eco-zone, and montane region ecozone (NDDC, 2006). It is richly endowed with abundant crude oil and gas reserves, which collectively accounts for about $90 \%$ of the nation's earnings, as well as other minerals (NDDC, 2006). The region is dominated by significant proportion of young people with over $62 \%$ of the population below the age of 30 years spreading across its 185 local government areas and 40 ethnic nationalities speaking over 250 indigenous languages and dialects (NNDC 2006). Predominant activities in the region beside the oil and gas sector include fishing, farming, trading and traditional arts (NDDC, 2006).

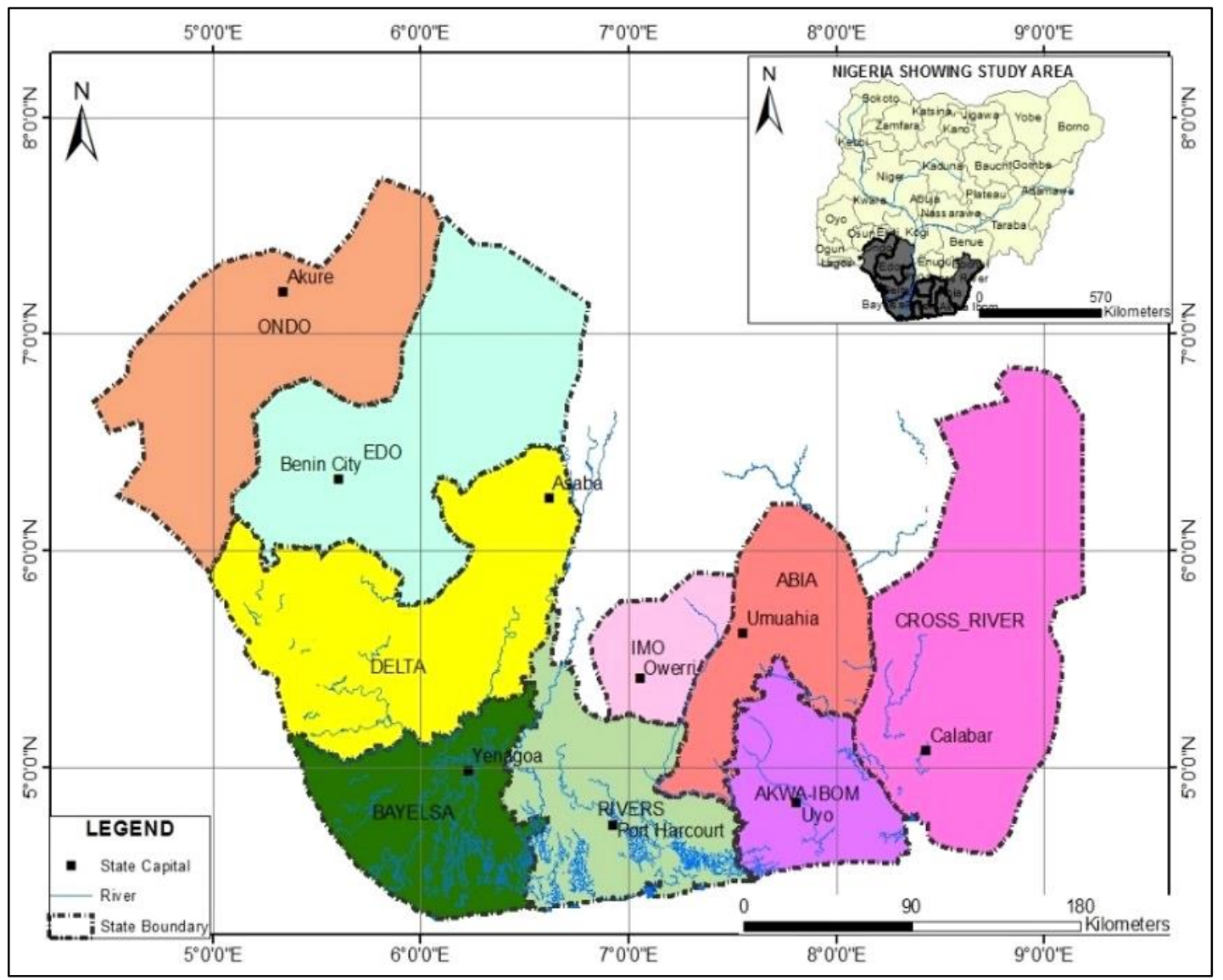

Figure 1. Niger Delta Region showing states

\subsection{Methods}

This study adopted the cross-sectional and descriptive research designs, while the target population of the study comprised the nine states that make up the Niger Delta region of Nigeria with a projected population 51,778,831 people as at 2021. The Capital Cities of all the nine states that make up the Niger Delta Region, namely; Akure, Asaba, Benin, Calabar, Owerri, Port Harcourt, Umuahia, Uyo, and Yanegoa where purposively selected for the study; while the simple random sampling technique was used to select the study subjects. The primary data emanated from administration of a multiple-option questionnaire; while the secondary data were obtained from available literature on the subject matter from books, journals, and newspapers. For sake of ease of computation and presentation, the 
selected cities were encoded as follows: Akure - AKU; Asaba - ASA; Benin - BEN; Calabar - CAL; Owerri, - OWE; Port Harcourt - PHC; Umuahia - UMU; Uyo - UYO and Yenagoa - YEN. Table 1 shows the population of the selected cities, the study sample size which was derived with the Taro Yamane (1967) formula [43], and the sample size distribution for each of the cities based on proportional allocation with respected to the population of each of the sampled city. A total of 400 questionnaire was distributed and same returned and used for the analyses. The descriptive and inferential statistical tools were employed to analyse the data in which all analyses were done with the Statistical Packages for Social Sciences (SPSS) version 22. The Taro Yamane (1967) formula is given Equation 1:

$n=\frac{N}{1+N(e)^{2}}$

Where; $n$ is sample size required; $N$ is total population; $e$ is level of significance $(0.05)^{2}$ or level of tolerance; Thus:

$n=\frac{7,800,194}{1+7,800,194(0.05) 2}=\frac{7,800,194}{1+7,800,194(0.0025)}=400$

Table 1. Sample Size Determination and Distribution for Each Selected Urban Area

\begin{tabular}{rccccc}
\hline S/N & $\begin{array}{c}\text { States selected by } \\
\text { purposive sampling }\end{array}$ & $\begin{array}{c}\text { Population of Urban } \\
\text { Areas by 1991 census }\end{array}$ & $\begin{array}{c}\text { Population of Urban } \\
\text { Areas by 2006 census }\end{array}$ & $\begin{array}{c}\text { Population of Urban Areas } \\
\text { by 2021 projected from 2006 }\end{array}$ & $\begin{array}{c}\text { Distribution of sample size by } \\
\text { proportional allocation }\end{array}$ \\
\hline 1 & Akure & 239,124 & 425,000 & 671,550 & 34 \\
2 & Asaba & 49,725 & 149,603 & 244,322 & 13 \\
3 & Benin & 762,719 & $1,140,000$ & $1,729,839$ & 89 \\
4 & Calabar & 310,839 & 375,196 & 583,152 & 30 \\
5 & Owerri & 119,711 & 390,000 & 635,014 & 33 \\
6 & Port Harcourt & 703,421 & $1,480,000$ & $2,464,631$ & 126 \\
7 & Umahia & 147,167 & 259.230 & 391,003 & 20 \\
8 & Uyo & 244,762 & 315,000 & 532,495 & 27 \\
9 & Yenagoa & N/A & 352,285 & 548,188 & 28 \\
\hline \multicolumn{7}{r}{} & Total & $\mathbf{2 , 5 7 7 , 4 6 8}$ & $\mathbf{4 , 8 8 6 , 3 1 4}$ & $\mathbf{7 , 8 0 0 , 1 9 4}$ \\
\hline
\end{tabular}

NB: (a). The growth rates for the states are Abia $=2.74 \%$, Akwa Ibom $=3.5 \%$, Bayelsa $=2.96 \%$, Cross River $=2.94 \%$, Delta $=3.27 \%$, Edo $=2.78 \%$, Imo $=3.25 \%$, Ondo $=$ $3.05 \%$, Rivers $=3.47 \%$; (b). Population figures are based on the National Population Commission 1991 census and 2006 national census final results; (c) The 2021 population are based on the researcher's projections estimated from 2006 national census figures.

\section{Results and Discussions}

\subsection{Socio-Economic and Demographic Characteristics}

The results on the socio-economic and demographic characteristics of the respondents in the Niger Delta Region are presented in Table 2. The result shows that male respondents were more in number $(63.50 \%)$ than their female counterparts (36.50\%); while the major age bracket was $26-35$ years $(32.25 \%)$; followed in rank by age brackets $36-45$ years $(26.25 \%)$; $18-25$ years $(22.00 \%)$; 56 years and above $(10.25 \%)$; and $46-55$ years $(9.25 \%)$. This finding on age suggests that majority of the residents in the cities are mainly composed of youth population, and this verifies an earlier report of the Niger Delta Development Commission (NDDC) (2006) which proclaimed that the Niger Delta region is dominated majorly by greater population of youths with over $62 \%$ of the population being below the age of 30 years, whereas adults in the age group of 30-69 years (which also includes some young people) constitute only $36 \%$ while the remaining $2 \%$ of the population are those aged of 70 years and above (NNDC, 2006).

It was revealed that on the highest level of education attained by the respondents those with Bachelor of Science (BSc) degree were in majority (33.75\%); those with West African Senior Secondary Certificate/Senior Secondary Certificate (WASSC/SSC) and its equivalents followed with 15.5\%; those that possess Master of Science (MSc) degree were 15.25\%; Higher National Diploma (HND) holders were 13.50\%; National Diploma (ND) holders constituted 12.75\%; First School Leaving Certificate (FSLC) holders covered 5.0\%; Doctor of Philosophy (PhD) holders were $3.25 \%$; while those without any educational qualification were a meagre $1.0 \%$. This finding signifies that these states where some residents did not obtain any educational qualifications seem to be the educationally disadvantaged in the region.

The findings on occupation of residents in hierarchy show that greater proportion of the respondents were civil/public servants (44.5\%); while the skilled/self-employed covered $17.0 \%$; students represented $14.0 \%$; trader/businessmen took $13.5 \%$; those engaged in farming/fishing covered $7.5 \%$; and the unemployed residents were $3.5 \%$. It follows from this results that agrarian activities are almost non-existing in the urban environments. Regarding annual income, it was reveals that $\$ 216,000^{*}$ and below was the popular annual income bracket of the respondents

${ }^{*} 1 \mathrm{~N}=0.0024 \$$ 
(34.0\%); followed in succession by income brackets $\$ 217,000$ - $\$ 400,000$ (18.5\%); $\$ 1,000,000$ and above (16.75\%); $\$ 801,000$ - $\$ 1,000,000$ (12.75\%); $\$ 601,000$ - $\$ 800,000$ (7.0\%); while income bracket $\$ 401,000$ - $\$ 600,000$ and those that do not earn any income represented 5.5\% each. This finding on income presupposes that majority of the residents in the Niger Delta are living below the extant national minimum wage of $\$ 30,000$ which would translate to $\$ 360,000$ per annum and this scenario culminates to the fact that poverty rate in the Niger Delta region is very high.

Table 2. Socio-Economic and Demographic Characteristics

\begin{tabular}{|c|c|c|c|c|c|c|c|c|c|c|c|}
\hline Urban Areas & $\mathbf{A K U}$ & ASA & BEN & CAL & OWE & PHC & UMU & UYO & YEN & Total freq. & $\%$ \\
\hline \multicolumn{12}{|c|}{ Gender } \\
\hline Male & 22 & 3 & 51 & 19 & 22 & 84 & 12 & 20 & 21 & 254 & 63.50 \\
\hline Female & 12 & 10 & 38 & 11 & 11 & 42 & 8 & 7 & 7 & 146 & 36.50 \\
\hline Total & 34 & 13 & 89 & 30 & 33 & 126 & 20 & 27 & 28 & 400 & 100 \\
\hline \multicolumn{12}{|c|}{ Age } \\
\hline $18-25$ & 7 & 2 & 15 & 6 & 7 & 33 & 4 & 6 & 8 & 88 & 22.00 \\
\hline $26-35$ & 5 & 4 & 21 & 9 & 11 & 55 & 4 & 8 & 12 & 129 & 32.25 \\
\hline $36-45$ & 12 & 7 & 32 & 10 & 9 & 13 & 9 & 9 & 4 & 105 & 26.25 \\
\hline $46-55$ & 8 & 0 & 13 & 3 & 5 & 3 & 2 & 3 & 0 & 37 & 9.25 \\
\hline $56 \&$ above & 2 & 0 & 8 & 2 & 1 & 22 & 1 & 1 & 4 & 41 & 10.25 \\
\hline Total & 34 & 13 & 89 & 30 & 33 & 126 & 20 & 27 & 28 & 400 & 100 \\
\hline \multicolumn{12}{|c|}{ Highest Educational Qualification } \\
\hline FSLC & 0 & 0 & 10 & 2 & 0 & 3 & 0 & 5 & 0 & 20 & 5.00 \\
\hline WASC/SSC & 0 & 2 & 19 & 8 & 0 & 12 & 0 & 8 & 13 & 62 & 15.50 \\
\hline ND & 0 & 3 & 18 & 4 & 6 & 12 & 3 & 5 & 0 & 51 & 12.75 \\
\hline HND & 16 & 2 & 17 & 6 & 0 & 0 & 4 & 4 & 5 & 54 & 13.50 \\
\hline $\mathrm{BSc}$ & 9 & 5 & 16 & 5 & 16 & 65 & 9 & 3 & 7 & 135 & 33.75 \\
\hline MSc & 6 & 0 & 6 & 2 & 8 & 31 & 4 & 1 & 3 & 61 & 15.25 \\
\hline $\mathrm{PhD}$ & 3 & 0 & 3 & 1 & 3 & 3 & 0 & 0 & 0 & 13 & 3.25 \\
\hline None & 0 & 1 & 0 & 2 & 0 & 0 & 0 & 1 & 0 & 4 & 1.00 \\
\hline Total & 34 & 13 & 89 & 30 & 33 & 126 & 20 & 27 & 28 & 400 & 100 \\
\hline \multicolumn{12}{|c|}{ Occupation } \\
\hline Student & 0 & 0 & 14 & 7 & 0 & 17 & 5 & 7 & 6 & 56 & 14.00 \\
\hline Farming / Fishing & 6 & 0 & 11 & 2 & 0 & 6 & 0 & 5 & 0 & 30 & 7.50 \\
\hline Civil/Public Service & 19 & 13 & 25 & 9 & 15 & 75 & 8 & 8 & 6 & 178 & 44.50 \\
\hline Trading / Business & 4 & 0 & 16 & 5 & 12 & 7 & 4 & 3 & 3 & 54 & 13.50 \\
\hline Skilled/Self Employed & 5 & 0 & 15 & 4 & 6 & 21 & 3 & 3 & 11 & 68 & 17.00 \\
\hline Unemployed & 0 & 0 & 8 & 3 & 0 & 0 & 0 & 1 & 2 & 14 & 3.50 \\
\hline Total & 34 & 13 & 89 & 30 & 33 & 126 & 20 & 27 & 28 & 400 & 100 \\
\hline \multicolumn{12}{|c|}{ Income Per Annum } \\
\hline $216,000 \&$ below & 5 & 6 & 21 & 11 & 5 & 64 & 6 & 6 & 12 & 136 & 34.00 \\
\hline $217,000-400,000$ & 3 & 2 & 15 & 8 & 10 & 20 & 0 & 11 & 5 & 74 & 18.50 \\
\hline $401,000-600,000$ & 0 & 2 & 11 & 3 & 3 & 0 & 0 & 3 & 0 & 22 & 5.50 \\
\hline $601,000-800,000$ & 5 & 1 & 14 & 3 & 3 & 0 & 0 & 2 & 0 & 28 & 7.00 \\
\hline $801,000-1,000,000$ & 3 & 2 & 8 & 1 & 7 & 21 & 3 & 2 & 4 & 51 & 12.75 \\
\hline $1,000,000 \&$ above & 18 & 0 & 4 & 1 & 5 & 21 & 11 & 2 & 5 & 67 & 16.75 \\
\hline None & 0 & 0 & 16 & 3 & 0 & 0 & 0 & 1 & 2 & 22 & 5.50 \\
\hline Total & 34 & 13 & 89 & 30 & 33 & 126 & 20 & 27 & 28 & 400 & 100 \\
\hline
\end{tabular}

\subsection{Perception of Air Temperature by Residents}

The result on perception of air temperature in Table 3 shows that above three quarters of the sampled population $(77.5 \%)$ were aware of the impacts of temperature in the urban environment; while $16.0 \%$ were not; and $6.5 \%$ were undecided. Also, majority of the residents rated the temperature in the neighborhood as high $(49.25 \%) ; 44.5 \%$ rated it 
as moderate; $3.5 \%$ rated it as cool; $2.75 \%$ rated it as extremely high; while none rated it as extremely cold. It was also found that above half of the residents were not aware of the comfort threshold of air temperature (50.50\%); while $44.25 \%$ were aware; and $5.25 \%$ were neutral.

The findings indicate that majority of the respondents $(59.0 \%)$ were aware of the health effects of temperature; while $38.25 \%$ were not aware; and $2.75 \%$ were neutral. Nonetheless, not being aware of the health impacts of high temperature may overlap to not taking any mitigation measures, which may afterwards lead to more adverse conditions. Again, more than half of the sampled population $(64.50 \%)$ had never taken personal steps to lessen high temperature; while $33.0 \%$ had taken; and $2.50 \%$ were neutral. This adamant posture in taking personal actions to mitigate the high temperature sensations could be as a result of the respondents' high level of ignorance towards comfort threshold and health impacts of high temperatures. It was also found that majority of the residents covering $60.25 \%$ were not satisfied with the level of temperature in their urban environment; while $36.25 \%$ were satisfied; and $3.50 \%$ were neutral. This high temperature sensations experienced in the Niger Delta confirms the report of the National Oceanic and Atmospheric Administration (NOAA) cited in the 2020 temperature evaluation report of the Nigerian Meteorological Agency (NiMet) (2020) [44], that to date 2020 remains the second warmest year since 141 years.

Table 3. Perception on Air Temperature

\begin{tabular}{|c|c|c|c|c|c|c|c|c|c|c|c|}
\hline Urban Areas & AKU & ASA & BEN & CAL & OWE & PHC & UMU & UYO & YEN & Total freq. & $\%$ \\
\hline \multicolumn{12}{|c|}{ Awareness of the impacts of temperature in the urban environment } \\
\hline Yes & 28 & 9 & 81 & 16 & 4 & 121 & 10 & 17 & 24 & 310 & 77.50 \\
\hline No & 6 & 2 & 5 & 12 & 29 & 0 & 0 & 10 & 0 & 64 & 16.00 \\
\hline Undecided & 0 & 2 & 3 & 2 & 0 & 5 & 10 & 0 & 4 & 26 & 6.50 \\
\hline Total & 34 & 13 & 89 & 30 & 33 & 126 & 20 & 27 & 28 & 400 & 100 \\
\hline \multicolumn{12}{|c|}{ Rating of temperature in the neighborhood } \\
\hline Extremely high & 3 & 0 & 0 & 0 & 0 & 8 & 0 & 0 & 0 & 11 & 2.75 \\
\hline High & 11 & 10 & 43 & 14 & 25 & 63 & 10 & 13 & 8 & 197 & 49.25 \\
\hline Moderate & 20 & 0 & 46 & 16 & 8 & 55 & 10 & 11 & 12 & 178 & 44.50 \\
\hline Cool & 0 & 3 & 0 & 0 & 0 & 0 & 0 & 3 & 8 & 14 & 3.50 \\
\hline Extremely cold & 0 & 0 & 0 & 0 & 0 & 0 & 0 & 0 & 0 & 0 & 0.00 \\
\hline Total & 34 & 13 & 89 & 30 & 33 & 126 & 20 & 27 & 28 & 400 & 100 \\
\hline \multicolumn{12}{|c|}{ Awareness of the comfort threshold of temperature } \\
\hline Yes & 18 & 3 & 24 & 14 & 24 & 46 & 20 & 11 & 17 & 177 & 44.25 \\
\hline No & 13 & 7 & 60 & 14 & 9 & 74 & 0 & 16 & 9 & 202 & 50.50 \\
\hline Undecided & 3 & 3 & 5 & 2 & 0 & 6 & 0 & 0 & 2 & 21 & 5.25 \\
\hline Total & 34 & 13 & 89 & 30 & 33 & 126 & 20 & 27 & 28 & 400 & 100 \\
\hline \multicolumn{12}{|c|}{ Awareness of the health effect of temperature } \\
\hline Yes & 19 & 11 & 30 & 14 & 27 & 92 & 10 & 9 & 24 & 236 & 59.00 \\
\hline No & 13 & 1 & 56 & 16 & 6 & 31 & 10 & 18 & 2 & 153 & 38.25 \\
\hline Neutral & 2 & 1 & 3 & 0 & 0 & 3 & 0 & 0 & 2 & 11 & 2.75 \\
\hline Total & 34 & 13 & 89 & 30 & 33 & 126 & 20 & 27 & 28 & 400 & 100 \\
\hline \multicolumn{12}{|c|}{ Taken personal steps to lessen high temperature } \\
\hline Yes & 12 & 9 & 18 & 8 & 20 & 21 & 20 & 10 & 14 & 132 & 33.00 \\
\hline No & 19 & 2 & 71 & 22 & 13 & 102 & 0 & 17 & 12 & 258 & 64.50 \\
\hline Neutral & 3 & 2 & 0 & 0 & 0 & 3 & 0 & 0 & 2 & 10 & 2.50 \\
\hline Total & 34 & 13 & 89 & 30 & 33 & 126 & 20 & 27 & 28 & 400 & 100 \\
\hline \multicolumn{12}{|c|}{ Satisfaction with the level of temperature in the urban environment } \\
\hline Yes & 11 & 5 & 19 & 12 & 17 & 59 & 0 & 8 & 14 & 145 & 36.25 \\
\hline No & 21 & 4 & 70 & 18 & 14 & 65 & 18 & 19 & 12 & 241 & 60.25 \\
\hline Neutral & 2 & 4 & 0 & 0 & 2 & 2 & 2 & 0 & 2 & 14 & 3.50 \\
\hline Total & 34 & 13 & 89 & 30 & 33 & 126 & 20 & 27 & 28 & 400 & 100 \\
\hline
\end{tabular}

\subsection{Perceived Causes of High Air Temperature}

Table 4 shows the result on the perceived causes of high air temperature in the Niger Delta, and indicates that 3/4 majority of the respondents $(75.0 \%)$ agreed that urban growth and rise in population contribute to high temperature 
levels in the cities; while (18.0\%) disagreed and 6.5\% was neutral. Also, $61.0 \%$ of the respondents agreed that construction materials of surfaces (roads, roofs, buildings etc.) are implicative to high temperatures in the urban areas; $36.25 \%$ disagreed; while $2.75 \%$ was neutral. The result also shows that more than $2 / 3$ of the respondents agreed that removal of trees and other vegetation leads to increase in the urban temperature; while $26.25 \%$ disagreed and $6.25 \%$ was neutral. On city structure/street layout (that is, street geometry), above half of the respondents representing $54.5 \%$ disagreed that street geometry play any role in increase in the cities' temperature; while $40.5 \%$ agreed and $5.0 \%$ was neutral.

It is also discovered that majority of the respondents (76.25\%) agreed that manmade heat (e.g., bush/waste/material burning) lead to increase in the temperature of the cities; $17.25 \%$ disagreed; while $6.5 \%$ was neutral. Similarly, $75.0 \%$ of the respondents agreed that emission of air pollutants (greenhouse gases, generator fumes, vehicle etc.) contributes to high temperature regimes in the urban areas; while $18.5 \%$ disagreed and $6.5 \%$ was neutral. Regarding dense concentration/congestion of buildings, majority (50.25\%) indicated the affirmative; while $44.75 \%$ disagreed; and $5.0 \%$ was neutral. Again, majority of the respondents $(82.5 \%)$ agreed that time of season influences high temperatures in the urban areas; $11.0 \%$ disagreed while $6.5 \%$ was neutral.

Table 4. Perceived Causes of High Air Temperature

\begin{tabular}{|c|c|c|c|c|c|c|c|c|c|c|c|}
\hline Urban Areas & $\mathbf{A K U}$ & ASA & BEN & CAL & OWE & PHC & UMU & UYO & YEN & Total Freq. & $\%$ \\
\hline \multicolumn{12}{|c|}{ Urbanisation (City growth and population) } \\
\hline Agree & 28 & 9 & 81 & 16 & 4 & 111 & 10 & 17 & 24 & 300 & 75.00 \\
\hline Neutral & 0 & 2 & 3 & 2 & 0 & 5 & 10 & 0 & 4 & 26 & 6.50 \\
\hline Disagree & 6 & 2 & 5 & 12 & 29 & 10 & 0 & 10 & 0 & 74 & 18.0 \\
\hline Total & 34 & 13 & 89 & 30 & 33 & 126 & 20 & 27 & 28 & 400 & 100 \\
\hline \multicolumn{12}{|c|}{ Construction materials of surfaces (roads, roofs, buildings etc.) } \\
\hline Agree & 19 & 11 & 30 & 14 & 27 & 92 & 10 & 9 & 24 & 244 & 61.00 \\
\hline Neutral & 2 & 1 & 3 & 0 & 0 & 3 & 0 & 0 & 2 & 11 & 2.75 \\
\hline Disagree & 13 & 1 & 56 & 16 & 6 & 31 & 10 & 18 & 2 & 145 & 36.25 \\
\hline Total & 34 & 13 & 89 & 30 & 33 & 126 & 20 & 27 & 28 & 400 & 100 \\
\hline \multicolumn{12}{|c|}{ Removal of trees and other vegetation } \\
\hline Agree & 18 & 6 & 72 & 16 & 11 & 108 & 17 & 12 & 10 & 270 & 67.50 \\
\hline Neutral & 2 & 3 & 2 & 3 & 3 & 3 & 1 & 4 & 4 & 25 & 6.25 \\
\hline Disagree & 14 & 4 & 15 & 11 & 19 & 15 & 2 & 11 & 14 & 105 & 26.25 \\
\hline Total & 34 & 13 & 89 & 30 & 33 & 126 & 20 & 27 & 28 & 400 & 100 \\
\hline \multicolumn{12}{|c|}{ City structure/street layout } \\
\hline Agree & 12 & 9 & 28 & 8 & 20 & 41 & 20 & 10 & 14 & 162 & 40.50 \\
\hline Neutral & 3 & 2 & 0 & 0 & 0 & 13 & 0 & 0 & 2 & 20 & 5.0 \\
\hline Disagree & 19 & 2 & 61 & 22 & 13 & 72 & 0 & 17 & 12 & 218 & 54.50 \\
\hline Total & 34 & 13 & 89 & 30 & 33 & 126 & 20 & 27 & 28 & 400 & 100 \\
\hline \multicolumn{12}{|c|}{ Manmade heat (e.g., bush/waste/material burning) } \\
\hline Agree & 28 & 9 & 81 & 16 & 4 & 116 & 10 & 17 & 24 & 305 & 76.25 \\
\hline Neutral & 0 & 2 & 3 & 2 & 0 & 5 & 10 & 0 & 4 & 26 & 6.50 \\
\hline Disagree & 6 & 2 & 5 & 12 & 29 & 5 & 0 & 10 & 0 & 69 & 17.25 \\
\hline Total & 34 & 13 & 89 & 30 & 33 & 126 & 20 & 27 & 28 & 400 & 100 \\
\hline \multicolumn{12}{|c|}{ Emission of air pollutants (greenhouse gases, generator fumes, vehicle etc.) } \\
\hline Agree & 28 & 9 & 81 & 16 & 4 & 111 & 10 & 17 & 24 & 300 & 75.00 \\
\hline Neutral & 0 & 2 & 3 & 2 & 0 & 5 & 10 & 0 & 4 & 26 & 6.50 \\
\hline Disagree & 6 & 2 & 5 & 12 & 29 & 20 & 0 & 10 & 0 & 74 & 18.50 \\
\hline Total & 34 & 13 & 89 & 30 & 33 & 126 & 20 & 27 & 28 & 400 & 100 \\
\hline \multicolumn{12}{|c|}{ Dense/congestion of buildings } \\
\hline Agree & 19 & 2 & 54 & 22 & 13 & 62 & 0 & 17 & 12 & 201 & 50.25 \\
\hline Neutral & 3 & 2 & 0 & 0 & 0 & 13 & 0 & 0 & 2 & 20 & 5.0 \\
\hline Disagree & 12 & 9 & 35 & 8 & 20 & 51 & 20 & 10 & 14 & 179 & 44.75 \\
\hline Total & 34 & 13 & 89 & 30 & 33 & 126 & 20 & 27 & 28 & 400 & 100 \\
\hline \multicolumn{12}{|c|}{ Time of season } \\
\hline Agree & 28 & 9 & 86 & 16 & 19 & 121 & 10 & 17 & 24 & 330 & 82.50 \\
\hline Neutral & 0 & 2 & 3 & 2 & 0 & 5 & 10 & 0 & 4 & 26 & 6.50 \\
\hline Disagree & 6 & 2 & 0 & 12 & 14 & 0 & 0 & 10 & 0 & 44 & 11.00 \\
\hline Total & 34 & 13 & 89 & 30 & 33 & 126 & 20 & 27 & 28 & 400 & 100 \\
\hline
\end{tabular}




\subsection{Impacts and Problems Associated with Increasing Temperature}

The analyses in Table 5 indicates that nearly all the respondents $(95.50 \%)$ strongly agreed that human discomfort is a problem associated with increasing temperature; while $4.50 \%$ agreed; and none of them disagreed or strongly disagreed. It also shows that more than $2 / 3$ of the respondents covering $71.50 \%$ strongly agreed that high temperature causes excessive heat; $25.75 \%$ agreed; $2.0 \%$ of them were neutral; while $0.75 \%$ disagreed and none strongly disagreed. Furthermore, the result reveals that above $2 / 3$ of the sampled population $(67.50 \%)$ agreed that high temperature causes illness and diseases; $14.0 \%$ of them disagreed; $6.75 \%$ strongly agreed; $6.25 \%$ was neutral; while $5.5 \%$ strongly disagreed. Again, the findings show that majority of the respondents representing $(46.75 \%)$ disagreed that high temperature leads to death; $25.0 \%$ agreed; $10.50 \%$ strongly disagreed; $9.50 \%$ was neutral; while $8.25 \%$ strongly agreed. The analyses again, reveals that majority of the respondents $(36.0 \%)$ agreed that high temperature causes soil aridity/lack of water in soil for plant growth; $31.25 \%$ strongly agreed; $20.0 \%$ disagreed; $8.0 \%$ was neutral; while $4.75 \%$ strongly disagreed.

Concerning the impact of high temperature on forest/bush fires, $34.75 \%$ being the majority of the respondents was neutral on whether or not high temperatures is implicated in forest/bush fires; $27.25 \%$ agreed that high temperature exacerbate forest/bush fires; $24.50 \%$ strongly agreed; $11.0 \%$ disagreed; while $2.50 \%$ strongly disagreed. The implication of this result is that majority of the residents in Niger Delta may be oblivious of the nexus between high temperature and wild fires. It is also shown that majority of the respondents $(45.75 \%)$ agreed that poor air quality is a problem of extreme temperature; $27.75 \%$ disagreed; $13.25 \%$ strongly agreed; while $12.75 \%$ were neutral and $0.50 \%$ strongly disagreed. Also, while majority (33.50\%) agreed that high temperature leads to increase in diseases vectors; $27.75 \%$ of them disagreed; $19.50 \%$ was neutral; $12.75 \%$ strongly agreed; and $6.50 \%$ strongly disagreed.

The result again reveals that majority of the sampled population $(42.75 \%)$ agreed that high temperature is implicative to increase in energy/electricity demand and usage; $36.50 \%$ strongly agreed; $13.75 \%$ disagreed; $7.0 \%$ was neutral; while none strongly disagreed. This increase in energy demand cum usage manifest in the use of airconditioners and electric fans during heat periods and the use of heating facilities during periods of cold. Though, according to the Organsation for Economic Co-operation and Development (OECD, 2008) [45], such energy demand and consumption will be governed by the income at the disposal of the would-be user. It was found that about $2 / 3$ of the respondents $(65.75 \%)$ strongly agreed that dehydration of the body and regular thirst for water are effects of high temperature; $32.50 \%$ agreed; $1.75 \%$ was neutral; and neither of them disagreed or strongly disagreed.

Table 5. Impacts and Problems Associated with High/Increasing Temperature

\begin{tabular}{|c|c|c|c|c|c|c|c|c|c|c|c|}
\hline Urban Areas & $\mathbf{A K U}$ & ASA & BEN & CAL & OWE & PHC & UMU & UYO & YEN & Total freq. & $\%$ \\
\hline \multicolumn{12}{|c|}{ Human discomfort } \\
\hline Strongly agree & 34 & 6 & 89 & 30 & 30 & 126 & 18 & 27 & 22 & 382 & 95.50 \\
\hline Agree & 0 & 7 & 0 & 0 & 3 & 0 & 2 & 0 & 6 & 18 & 4.50 \\
\hline Neutral & 0 & 0 & 0 & 0 & 0 & 0 & 0 & 0 & 0 & 0 & 0.00 \\
\hline Disagree & 0 & 0 & 0 & 0 & 0 & 0 & 0 & 0 & 0 & 0 & 0.00 \\
\hline Strongly Disagree & 0 & 0 & 0 & 0 & 0 & 0 & 0 & 0 & 0 & 0 & 0.00 \\
\hline Total & 34 & 13 & 89 & 30 & 33 & 126 & 20 & 27 & 28 & 400 & 100 \\
\hline \multicolumn{12}{|c|}{ Excessive heat } \\
\hline Strongly agree & 16 & 5 & 64 & 22 & 25 & 126 & 4 & 10 & 14 & 286 & 71.50 \\
\hline Agree & 12 & 6 & 25 & 8 & 6 & 0 & 15 & 17 & 14 & 103 & 25.75 \\
\hline Neutral & 3 & 2 & 0 & 0 & 2 & 0 & 1 & 0 & 0 & 8 & 2.00 \\
\hline Disagree & 3 & 0 & 0 & 0 & 0 & 0 & 0 & 0 & 0 & 3 & 0.75 \\
\hline Strongly Disagree & 0 & 0 & 0 & 0 & 0 & 0 & 0 & 0 & 0 & $\mathbf{0}$ & 0.00 \\
\hline Total & 34 & 13 & 89 & 30 & 33 & 126 & 20 & 27 & 28 & 400 & 100 \\
\hline \multicolumn{12}{|c|}{ Illness/disease } \\
\hline Strongly agree & 2 & 4 & 3 & 0 & 14 & 0 & 2 & 0 & 2 & 27 & 6.75 \\
\hline Agree & 18 & 6 & 72 & 16 & 11 & 108 & 17 & 12 & 10 & 270 & 67.50 \\
\hline Neutral & 2 & 3 & 2 & 3 & 3 & 3 & 1 & 4 & 4 & 25 & 6.25 \\
\hline Disagree & 10 & 0 & 6 & 7 & 5 & 13 & 0 & 6 & 9 & 56 & 14.00 \\
\hline Strongly Disagree & 2 & 0 & 6 & 4 & 0 & 2 & 0 & 5 & 3 & 22 & 5.50 \\
\hline Total & 34 & 13 & 89 & 30 & 33 & 126 & 20 & 27 & 28 & 400 & 100 \\
\hline
\end{tabular}




\begin{tabular}{|c|c|c|c|c|c|c|c|c|c|c|c|}
\hline \multicolumn{12}{|c|}{ Death of humans } \\
\hline Strongly agree & 0 & 2 & 6 & 0 & 10 & 13 & 0 & 0 & 2 & 33 & 8.25 \\
\hline Agree & 17 & 2 & 25 & 5 & 7 & 37 & 2 & 3 & 2 & 100 & 25.00 \\
\hline Neutral & 2 & 7 & 2 & 1 & 9 & 3 & 6 & 2 & 6 & 38 & 9.50 \\
\hline Disagree & 13 & 2 & 47 & 20 & 7 & 60 & 10 & 16 & 12 & 187 & 46.75 \\
\hline Strongly Disagree & 2 & 0 & 9 & 4 & 0 & 13 & 2 & 6 & 6 & 42 & 10.50 \\
\hline Total & 34 & 13 & 89 & 30 & 33 & 126 & 20 & 27 & 28 & 400 & 100 \\
\hline \multicolumn{12}{|c|}{ Aridity/lack of water in soil for plant growth } \\
\hline Strongly agree & 10 & 4 & 34 & 4 & 5 & 55 & 6 & 3 & 4 & 125 & 31.25 \\
\hline Agree & 15 & 3 & 26 & 16 & 16 & 33 & 12 & 9 & 14 & 144 & 36.00 \\
\hline Neutral & 3 & 3 & 4 & 2 & 6 & 6 & 2 & 2 & 4 & 32 & 8.00 \\
\hline Disagree & 6 & 3 & 20 & 5 & 3 & 26 & 0 & 11 & 6 & 80 & 20.00 \\
\hline Strongly Disagree & 0 & 0 & 5 & 3 & 3 & 6 & 0 & 2 & 0 & 19 & 4.75 \\
\hline Total & 34 & 13 & 89 & 30 & 33 & 126 & 20 & 27 & 28 & 400 & 100 \\
\hline \multicolumn{12}{|c|}{ Forest/bush fires } \\
\hline Strongly agree & 6 & 2 & 29 & 6 & 4 & 38 & 0 & 7 & 6 & 98 & 24.50 \\
\hline Agree & 14 & 6 & 20 & 14 & 8 & 28 & 0 & 9 & 10 & 109 & 27.25 \\
\hline Neutral & 7 & 5 & 35 & 6 & 1 & 60 & 13 & 8 & 4 & 139 & 34.75 \\
\hline Disagree & 7 & 0 & 5 & 4 & 12 & 0 & 7 & 3 & 6 & 44 & 11.00 \\
\hline Strongly Disagree & 0 & 0 & 0 & 0 & 8 & 0 & 0 & 0 & 2 & 10 & 2.50 \\
\hline Total & 34 & 13 & 89 & 30 & 33 & 126 & 20 & 27 & 28 & 400 & 100 \\
\hline \multicolumn{12}{|c|}{ Poor air quality } \\
\hline Strongly agree & 0 & 4 & 12 & 0 & 14 & 15 & 0 & 2 & 6 & 53 & 13.25 \\
\hline Agree & 20 & 5 & 36 & 12 & 17 & 56 & 16 & 12 & 9 & 183 & 45.75 \\
\hline Neutral & 3 & 4 & 11 & 4 & 2 & 20 & 2 & 2 & 3 & 51 & 12.75 \\
\hline Disagree & 11 & 0 & 30 & 14 & 0 & 35 & 2 & 11 & 8 & 111 & 27.75 \\
\hline Strongly Disagree & 0 & 0 & 0 & 0 & 0 & 0 & 0 & 0 & 2 & 2 & 0.50 \\
\hline Total & 34 & 13 & 89 & 30 & 33 & 126 & 20 & 27 & 28 & 400 & 100 \\
\hline \multicolumn{12}{|c|}{ Increase in diseases vectors } \\
\hline Strongly agree & 0 & 5 & 8 & 0 & 12 & 22 & 0 & 0 & 4 & 51 & 12.75 \\
\hline Agree & 18 & 3 & 31 & 12 & 5 & 44 & 6 & 7 & 8 & 134 & 33.50 \\
\hline Neutral & 4 & 5 & 16 & 4 & 12 & 13 & 12 & 10 & 2 & 78 & 19.50 \\
\hline Disagree & 10 & 0 & 30 & 12 & 4 & 33 & 2 & 8 & 12 & 111 & 27.75 \\
\hline Strongly Disagree & 2 & 0 & 4 & 2 & 0 & 14 & 0 & 2 & 2 & 26 & 6.50 \\
\hline Total & 34 & 13 & 89 & 30 & 33 & 126 & 20 & 27 & 28 & 400 & 100 \\
\hline \multicolumn{12}{|c|}{ Increase in energy/electricity demand and usage } \\
\hline Strongly agree & 10 & 4 & 29 & 8 & 16 & 48 & 14 & 9 & 8 & 146 & 36.50 \\
\hline Agree & 16 & 6 & 42 & 16 & 7 & 52 & 5 & 15 & 12 & 171 & 42.75 \\
\hline Neutral & 3 & 1 & 6 & 2 & 3 & 8 & 1 & 1 & 3 & 28 & 7.00 \\
\hline Disagree & 5 & 2 & 12 & 4 & 7 & 18 & 0 & 2 & 5 & 55 & 13.75 \\
\hline Strongly Disagree & 0 & 0 & 0 & 0 & 0 & 0 & 0 & 0 & 0 & 0 & 0.00 \\
\hline Total & 34 & 13 & 89 & 30 & 33 & 126 & 20 & 27 & 28 & 400 & 100 \\
\hline \multicolumn{12}{|c|}{ Dehydration of the body/regular thirst for water } \\
\hline Strongly agree & 18 & 10 & 61 & 22 & 28 & 80 & 12 & 14 & 18 & 263 & 65.75 \\
\hline Agree & 10 & 3 & 28 & 8 & 4 & 46 & 8 & 13 & 10 & 130 & 32.50 \\
\hline Neutral & 6 & 0 & 0 & 0 & 1 & 0 & 0 & 0 & 0 & 7 & 1.75 \\
\hline Disagree & 0 & 0 & 0 & 0 & 0 & 0 & 0 & 0 & 0 & 0 & 0.00 \\
\hline Strongly Disagree & 0 & 0 & 0 & 0 & 0 & 0 & 0 & 0 & 0 & 0 & 0.00 \\
\hline Total & 34 & 13 & 89 & 30 & 33 & 126 & 20 & 27 & 28 & 400 & 100 \\
\hline
\end{tabular}




\subsection{Measures Taken to Mitigate Impact of High Temperature}

Table 6 shows the result of the individual measures taken by residents of the selected urban areas to mitigate the impact of increasing temperature in their respective cities. The analysis reveals that majority of the respondents $(50.25 \%)$ had not adopted strict compliance to development regulations as measure to mitigate high temperature; while $40.25 \%$ had; and $9.5 \%$ were neutral. This non-compliance to regulations will only exacerbate the already worsening temperature sensations of these residents. Again, more than half of the population sampled $(50.75 \%)$ had not used air-conditioners to mitigate impact of high temperature; whereas $44.75 \%$ had used; and $4.50 \%$ were neutral. Also, greater proportion $(63.50 \%)$ had used electric fans to mitigate high temperature; $34.75 \%$ had not; and $1.75 \%$ was neutral. It should be pointed out that the degree of usage of air-conditioners and electric fans is to some extent predicated on income status, personal preference and availability of energy supply, especially from the public mains. However, the sparse usage of air-conditioners and popular usage of electric fans may not necessarily be predicated on issues of affordability but majorly on the irregular public power supply which pushes majority of the residents to resort to smaller electricity generating sets whose capacity cannot run air-conditioners but only fans.

More than 4/5 of the population (92.50\%) had adopted drinking of plenty water to mitigate high temperature; $5.0 \%$ had not; and $2.50 \%$ were neutral. The result again reveals that above $2 / 3$ majority of the respondents $(66.50 \%)$ had not planted trees and other vegetation as high temperature mitigation measure; $29.75 \%$ had; and $3.75 \%$ were neutral. Majority $(38.0 \%)$ had also not adopted reduction in the release of air pollutants/greenhouse gases; while $37.25 \%$ had; and $24.75 \%$ were neutral. It was found that majority of the respondents $(62.0 \%)$ had not adopted creation of open spaces within their neighbourhoods as high temperature mitigation strategy; 28.75 of them had; while $9.25 \%$ were neutral. Furthermore, above half of the respondents (56.0\%) had not adopted reduction of activities that produce heat as part of high temperature mitigation measure; while $34.50 \%$ had; and $9.50 \%$ were neutral. Majority $(47.25 \%)$ had not used green infrastructure/cool roofs; whereas $35.75 \%$ had used; and $17.0 \%$ were neutral. Again, greater proportion of the respondents $(46.25 \%)$ had not allowed enough space between buildings as a measure to mitigate high temperature; $38.75 \%$ had; and $15.0 \%$ were neutral. While nearly all the respondents had taken at least one or more of the mitigation measures (99.75\%); 2 respondents representing $0.25 \%$ had not adopted any of the measures.

While an overwhelming majority of the sampled population (92.50\%) have applied the drinking of plenty of water as a mitigation plan, slightly above $2 / 3$ majority of the respondents $(66.50 \%)$ have never planted trees and other vegetation to cushion high temperatures, except in Akure and Owerri, where a majority of the respondents have planted trees. The analysis further shows that a greater proportion of the respondents (38.0\%) have not taken actions to reduce the release of air pollutants/greenhouse gases; but in Akure and Owerri, the majority of the respondents, as part of their high temperature alleviation strategy, have taken steps to reduce the release of air pollutants/greenhouse gases.

Table 6. Measures taken to mitigate Impact of Increasing Temperature

\begin{tabular}{|c|c|c|c|c|c|c|c|c|c|c|c|}
\hline Urban Areas & $\mathbf{A K U}$ & ASA & BEN & CAL & OWE & PHC & UMU & UYO & YEN & Total Freq. & $\%$ \\
\hline \multicolumn{12}{|c|}{ Strict compliance to development regulations and controls } \\
\hline Yes & 26 & 10 & 34 & 10 & 23 & 40 & 6 & 7 & 5 & 161 & 40.25 \\
\hline Neutral & 4 & 0 & 5 & 3 & 4 & 6 & 8 & 5 & 3 & 38 & 9.50 \\
\hline No & 4 & 3 & 50 & 17 & 6 & 80 & 6 & 15 & 20 & 201 & 50.25 \\
\hline Total & 34 & 13 & 89 & 30 & 33 & 126 & 20 & 27 & 28 & 400 & 100 \\
\hline \multicolumn{12}{|c|}{ Use of air conditioner } \\
\hline Yes & 10 & 8 & 39 & 12 & 23 & 58 & 7 & 10 & 12 & 179 & 44.75 \\
\hline Neutral & 3 & 2 & 0 & 4 & 2 & 0 & 7 & 0 & 0 & 18 & 4.50 \\
\hline No & 21 & 3 & 50 & 14 & 8 & 68 & 6 & 17 & 16 & 203 & 50.75 \\
\hline Total & 34 & 13 & 89 & 30 & 33 & 126 & 20 & 27 & 28 & 400 & 100 \\
\hline \multicolumn{12}{|c|}{ Use of electric fans } \\
\hline Yes & 26 & 10 & 55 & 24 & 27 & 72 & 10 & 13 & 17 & 254 & 63.50 \\
\hline Neutral & 1 & 0 & 0 & 0 & 0 & 2 & 2 & 2 & 0 & 7 & 1.75 \\
\hline No & 7 & 3 & 34 & 6 & 6 & 52 & 8 & 12 & 11 & 139 & 34.75 \\
\hline Total & 34 & 13 & 89 & 30 & 33 & 126 & 20 & 27 & 28 & 400 & 100 \\
\hline \multicolumn{12}{|c|}{ Drinking of plenty water } \\
\hline Yes & 32 & 11 & 86 & 25 & 26 & 123 & 19 & 23 & 25 & 370 & 92.50 \\
\hline Neutral & 2 & 0 & 3 & 0 & 0 & 2 & 1 & 2 & 0 & 10 & 2.50 \\
\hline No & 0 & 2 & 0 & 5 & 7 & 1 & 0 & 2 & 3 & 20 & 5.00 \\
\hline Total & 34 & 13 & 89 & 30 & 33 & 126 & 20 & 27 & 28 & 400 & 100 \\
\hline
\end{tabular}




\begin{tabular}{|c|c|c|c|c|c|c|c|c|c|c|c|}
\hline \multicolumn{12}{|c|}{ Planting of trees and other vegetation } \\
\hline Yes & 32 & 3 & 12 & 8 & 23 & 23 & 5 & 7 & 6 & 119 & 29.75 \\
\hline Neutral & 2 & 2 & 3 & 0 & 2 & 2 & 0 & 2 & 2 & 15 & 3.75 \\
\hline No & 0 & 8 & 74 & 22 & 8 & 101 & 15 & 18 & 20 & 266 & 66.50 \\
\hline Total & 34 & 13 & 89 & 30 & 33 & 126 & 20 & 27 & 28 & 400 & 100 \\
\hline \multicolumn{12}{|c|}{ Reduction in releasing air pollutants/greenhouse gases } \\
\hline Yes & 26 & 6 & 26 & 10 & 20 & 41 & 4 & 5 & 11 & 149 & 37.25 \\
\hline Neutral & 0 & 1 & 31 & 4 & 4 & 35 & 4 & 15 & 5 & 99 & 24.75 \\
\hline No & 8 & 6 & 32 & 16 & 9 & 50 & 12 & 7 & 12 & 152 & 38.00 \\
\hline Total & 34 & 13 & 89 & 30 & 33 & 126 & 20 & 27 & 28 & 400 & 100 \\
\hline \multicolumn{12}{|c|}{ Creating open spaces within the neighbourhood } \\
\hline Yes & 22 & 3 & 23 & 6 & 19 & 31 & 4 & 3 & 4 & 115 & 28.75 \\
\hline Neutral & 3 & 1 & 4 & 2 & 4 & 2 & 10 & 8 & 3 & 37 & 9.25 \\
\hline No & 9 & 9 & 62 & 22 & 10 & 93 & 6 & 16 & 21 & 248 & 62.00 \\
\hline Total & 34 & 13 & 89 & 30 & 33 & 126 & 20 & 27 & 28 & 400 & 100 \\
\hline \multicolumn{12}{|c|}{ Reducing activities that produce heat } \\
\hline Yes & 15 & 5 & 46 & 9 & 26 & 10 & 8 & 10 & 9 & 138 & 34.50 \\
\hline Neutral & 4 & 3 & 13 & 2 & 4 & 2 & 8 & 2 & 0 & 38 & 9.50 \\
\hline No & 15 & 5 & 30 & 19 & 3 & 114 & 4 & 15 & 19 & 224 & 56.00 \\
\hline Total & 34 & 13 & 89 & 30 & 33 & 126 & 20 & 27 & 28 & 400 & 100 \\
\hline \multicolumn{12}{|c|}{ Used green infrastructure/cool roofs } \\
\hline Yes & 13 & 3 & 45 & 2 & 9 & 57 & 6 & 3 & 5 & 143 & 35.75 \\
\hline Neutral & 4 & 6 & 4 & 4 & 11 & 4 & 11 & 11 & 13 & 68 & 17.00 \\
\hline No & 17 & 4 & 40 & 24 & 13 & 65 & 3 & 13 & 10 & 189 & 47.25 \\
\hline Total & 34 & 13 & 89 & 30 & 33 & 126 & 20 & 27 & 28 & 400 & 100 \\
\hline \multicolumn{12}{|c|}{ Allowed enough space between buildings } \\
\hline Yes & 22 & 4 & 42 & 12 & 10 & 50 & 6 & 4 & 5 & 155 & 38.75 \\
\hline Neutral & 6 & 1 & 5 & 4 & 8 & 11 & 7 & 8 & 10 & 60 & 15.00 \\
\hline No & 6 & 8 & 42 & 14 & 15 & 65 & 7 & 15 & 13 & 185 & 46.25 \\
\hline Total & 34 & 13 & 89 & 30 & 33 & 126 & 20 & 27 & 28 & 400 & 100 \\
\hline \multicolumn{12}{|c|}{ All of the above } \\
\hline Yes & 34 & 13 & 89 & 30 & 33 & 126 & 18 & 27 & 28 & 399 & 99.75 \\
\hline Neutral & 0 & 0 & 0 & 0 & 0 & 0 & 0 & 0 & 0 & 0 & 0.00 \\
\hline No & 0 & 0 & 0 & 0 & 0 & 0 & 0 & 1 & 0 & 1 & 0.25 \\
\hline Total & 34 & 13 & 89 & 30 & 33 & 126 & 20 & 27 & 28 & 400 & 100 \\
\hline \multicolumn{12}{|c|}{ None of the above } \\
\hline Yes & 0 & 0 & 0 & 0 & 0 & 0 & 1 & 0 & 0 & 1 & 0.25 \\
\hline Neutral & 0 & 0 & 0 & 0 & 0 & 0 & 0 & 0 & 0 & 0 & 0.00 \\
\hline No & 34 & 13 & 89 & 30 & 33 & 126 & 19 & 27 & 28 & 399 & 99.75 \\
\hline Total & 34 & 13 & 89 & 30 & 33 & 126 & 20 & 27 & 28 & 400 & 100 \\
\hline
\end{tabular}

\section{Conclusions and Recommendations}

This study was carried out in the capital cities of the nine states that constitute the Niger Delta Region with the aim of evaluating the factors of air temperature variability and mitigation strategies. The findings indicate that the majority of the residents of the Niger Delta cities were aware of the impacts of high temperatures in the cities and though they sensed the temperature in their milieus as high, they were at the same time not aware of the comfort threshold of air temperature but aware of the health effects of temperature, just as they had never taken personal steps to mitigate high temperatures. This high level of ignorance towards the comfort threshold and health impacts of high temperatures may be responsible for the residents' negligence or adamant posture towards applying personal mitigation measures, which may subsequently lead to more adverse conditions. The major factors perceived to be implicative to high temperature in the cities include urban growth and rise in population, construction materials of surfaces, removal of trees and other vegetation, manmade heat, emission of air pollutants, dense concentration/congestion of buildings, and time of season. 
Human discomfort, excessive heat, illness and diseases, soil aridity/lack of water in soil for plant growth, poor air quality, an increase in disease vectors, an increase in energy/electricity demand and usage, and dehydration of the body and regular thirst for water are found to be the major impacts and problems associated with high temperatures. The dominant measures adopted by residents to mitigate the impacts of high temperatures were only the use of electric fans and the drinking of plenty of water, while other viable measures were sparingly and scarcely applied. The study concludes that the majority of the residents of the region showed strong dissatisfaction towards the level of temperature in their cities amid the fact that they had never taken personal steps to mitigate high temperatures in their neighbourhoods, borne out of their lack of knowledge and negligence, which may subsequently lead to more adverse situations. Thus, this study offers the following recommendations:

- The planting and preservation of trees and other vegetation should be encouraged.

- Public enlightenment and awareness campaigns on practices that exacerbate high temperatures should be sponsored by the authorities.

- Regulatory agencies should strictly enforce planning regulations and control urban growth, and be committed to the enforcement of environmental policies. This is especially true because adequate spaces between buildings, street layout and/or geometry, neighborhood open spaces, and cross ventilation are all associated with high temperatures and their mitigation.

- The electricity infrastructure in the urban areas should be made sufficient and effective so as to promptly be applied in mitigating high temperature regimes via the use of air-conditioners and electric fans.

- The reorientation of citizens' attitudes and encouragement of friendly environmental practices and behaviors will to a large extent complement any other mitigation actions.

\section{Declarations}

\subsection{Author Contributions}

Conceptualization, A.P.S.; V.E.W.; M.O.N. and O.S.E.; methodology, A.P.S.; V.E.W., M.O.N. and O.S.E.; software, O.S.E.; validation, V.E.W., M.O.N. and O.S.E.; formal analysis, A.P.S.; investigation, A.P.S.; resources, A.P.S.; data curation, A.P.S.; writing - original draft preparation, A.P.S; writing-review and editing, A.P.S. and O.S.E.; visualization, A.P.S and O.S.E.; supervision, V.E.W.; M.O.N. and O.S.E.; project administration, A.P.S.; funding acquisition, A. P.C. All authors have read and agreed to the published version of the manuscript.

\subsection{Data Availability Statement}

The data presented in this study are available in article.

\subsection{Funding}

The authors received no financial support for the research, authorship, and/or publication of this article.

\subsection{Institutional Review Board Statement}

Not applicable.

\subsection{Informed Consent Statement}

Not applicable.

\subsection{Declaration of Competing Interest}

The authors declare that there is no conflict of interests regarding the publication of this manuscript. In addition, the ethical issues, including plagiarism, informed consent, misconduct, data fabrication and/or falsification, double publication and/or submission, and redundancies have been completely observed by the authors.

\section{References}

[1] United Nations, Department of Economic and Social Affairs (UN DESA), Population Division (2014a) World Urbanization Prospects: The 2014 Revision, Highlights (ST/ESA/SER.A/352). doi:10.18356/527e5125-en.

[2] United Nations, Department of Economic and Social Affairs (UN DESA), Population Division (2014b): 2014 Revision of the World Urbanization Prospects. The Population Division of the Department of Economic and Social Affairs of the United Nations, 10 July 2014, New York, United States.

[3] United Nations, Department of Economic and Social Affairs (UN DESA), Population Division (2018): 2018 Revision of World Urbanization Prospects. The Population Division of the Department of Economic and Social Affairs of the United Nations, 16 May 2018, New York, United States. 
[4] Revi, A., Satterthwaite, D. E., Aragón-Durand, F., Corfee-Morlot, J., Kiunsi, R. B. R., Pelling, M., Roberts, D. C., Solecki, W., Barros, V. R., Dokken, D. J., Mach, K. J., Mastrandrea, M. D., Bilir, T. E., Chatterjee, M., Ebi, K. L., Estrada, Y. O., Genova, R. C., Girma, B., Kissel, E. S., ... L.L. (2014). Urban Areas. In: Climate Change 2014: Impacts, Adaptation, and Vulnerability. Part A: Global and Sectoral Aspects. Contribution of Working Group II to the Fifth Assessment Report of the Intergovernmental Panel on Climate Change (pp. 535-612).

[5] Ayanlade, A. (2016). Variation in diurnal and seasonal urban land surface temperature: landuse change impacts assessment over Lagos metropolitan city. Modeling Earth Systems and Environment, 2(4), 1-8. doi:10.1007/s40808-016-0238-z.

[6] Gill, S., Handley, J., Ennos, A., \& Pauleit, S. (2007). Adapting Cities for Climate Change: The Role of the Green Infrastructure. Built Environment, 33(1), 115-133. doi:10.2148/benv.33.1.115.

[7] Fortuniak, K. (2009). Global environmental change and urban climate in Central European cities. In the southern Baltic region, 65 .

[8] Igun, E. (2017). Analysis and Sustainable Management of Urban Growth's Impact on Land Surface Temperature in Lagos, Nigeria. Journal of Remote Sensing \& GIS, 06(04), 2469-4134. doi:10.4172/2469-4134.1000212.

[9] Oke, T. R. (1973). City size and the urban heat island. Atmospheric Environment (1967), 7(8), 769-779. doi:10.1016/00046981(73)90140-6.

[10] Flores P, F., \& Lillo S, M. (2010). Simple Air Temperature Estimation Method from MODIS Satellite Images on a Regional Scale. Chilean Journal of Agricultural Research, 70(3), 436-445. doi:10.4067/s0718-58392010000300011.

[11] Hooker, J., Duveiller, G., \& Cescatti, A. (2018). Data descriptor: A global dataset of air temperature derived from satellite remote sensing and weather stations. Scientific Data, 5. doi:10.1038/sdata.2018.246.

[12] Voogt, J. A., \& Oke, T. R. (1997). Complete Urban Surface Temperatures, Journal of Applied Meteorology, 36(9), 1117-1132.

[13] Unger, J., Gal, T., Rakonczai, J., Mucsi, L., Szatmari, J., Tobak, Z., Van Leeuwen, B., \& Fiala, K. (2009). Air Temperature versus Surface Temperature in Urban Environment. The Seventh International Conference on Urban Climate, July, 3-6.

[14] Guan, K. (2011). Surface and ambient air temperatures associated with different ground material: a case study at the University of California, Berkeley. In Surface and Air Temperatures of Ground Material. California, United States.

[15] Srivanit, M., \& Hokao, K. (2012). Thermal infrared remote sensing for urban climate and environmental studies: An application for the city of Bangkok, Thailand. Journal of Architectural/Planning Research and Studies (JARS), 9(1), 83-100.

[16] Hong Kong Observatory (2018) Climate Change: Urbanization Effect. The Government of Hong Kong, Special Administrative Region; last revision date is on 22 Jan 2019, Hong Kong.

[17] Feulner, G., Rahmstorf, S., Levermann, A., \& Volkwardt, S. (2013). On the origin of the surface air temperature difference between the hemispheres in earth's present-day climate. Journal of Climate, 26(18), 7136-7150. doi:10.1175/JCLI-D-1200636.1.

[18] IPCC: Intergovernmental Panel on Climate Change (IPCC) (2018): Summary for Policymakers. Global warming of $1.5^{\circ} \mathrm{C}$. An IPCC Special Report on the impacts of global warming of $1.5^{\circ} \mathrm{C}$ above pre-industrial levels and related global greenhouse gas emission pathways, in the context of strengthening the global response to the threat of climate change,. In A. P. Shukla, W. Moufouma-Okia, C. Péan, R. Pidcock, S. Connors, J. B. R. Matthews, Y. Chen, X. Zhou, M. I. Gomis, E. Lonnoy, T. Maycock, M. Tignor, \& T. Waterfield (Eds.), IPCC - Sr15, 2(October), 17-20.

[19] Saadatabad, A. R., \& Bidokhti, A. A. (2011). Urbanization Effects on Local Climate in Tehran Megapolis. Research Journal of Environmental Sciences, 5(1), 1-21. doi:10.3923/rjes.2011.1.21.

[20] Aina, Y. A., Adam, E. M., \& Ahmed, F. (2017). Spatiotemporal Variations in the Impacts of Urban Land Use Types on Urban Heat Island Effects: The Case of Riyadh, Saudi Arabia. The International Archives of the Photogrammetry, Remote Sensing and Spatial Information Sciences, XLII-3/W2, 9-14. doi:10.5194/isprs-archives-xlii-3-w2-9-2017.

[21] Weng, Q. (2003). Fractal analysis of satellite-detected urban heat island effect. Photogrammetric Engineering and Remote Sensing, American Society for Photogrammetry and Remote Sensing, 69(5), 555-566. doi:10.14358/PERS.69.5.555.

[22] Manu, A., Twumasi, Y., \& Coleman, T. (2006). Is it global warming or the effect of urbanization? The rise in air temperature in two cities of Ghana. 5 International Federation of Surveyors Regional Conference for Africa, Accra, Ghana, 8-11 March.

[23] Dos Santos, T. O., De A Moura, G. B., Da Silva, B. B., De Oliveira, L. M. M., \& Machado, C. C. C. (2013). Influence of urbanization on land surface temperature in Recife city. Engenharia Agricola, 33(6), 1234-1244. doi:10.1590/S010069162013000600016.

[24] Zhang, J., \& Wu, L. (2017). Influence of human population movements on urban climate of Beijing during the Chinese New Year holiday. Scientific Reports, 7(45813). doi:10.1038/srep45813. 
[25] Lima, G. N. de, \& Magaña Rueda, V. O. (2018). The urban growth of the metropolitan area of Sao Paulo and its impact on the climate. Weather and Climate Extremes, 21, 17-26. doi:10.1016/j.wace.2018.05.002.

[26] Peace, N., \& Ezikorwor, W. (2018). Urban Warming in Port Harcourt Metropolis and Environs. Journal of Geography, Environment and Earth Science International, 14(4), 1-12. doi:10.9734/jgeesi/2018/41123.

[27] Peace, N. (2019). Geo-Spatial Dynamics of Land Surface Temperature of Port Harcourt Metropolis and Environs: Implication for Heat Disaster Management. Earth Sciences, 8(3), 169. doi:10.11648/j.earth.20190803.15.

[28] Trusilova, K., Jung, M., Churkina, G., Karsten, U., Heimann, M., \& Claussen, M. (2008). Urbanization impacts on the climate in Europe: Numerical experiments by the PSU-NCAR mesoscale model (MM5). Journal of Applied Meteorology and Climatology, 47(5), 1442-1455. doi:10.1175/2007JAMC1624.1

[29] Baker, L. A., Brazel, A. J., Selover, N., Martin, C., McIntyre, N., Steiner, F. R., ... Musacchio, L. (2002). Urbanization and warming of Phoenix (Arizona, USA): Impacts, feedbacks and mitigation, Urban Ecosystems, 6(3), $183-203$. doi:10.1023/a:1026101528700.

[30] Arifwidodo, S. D., \& Tanaka, T. (2015). The Characteristics of Urban Heat Island in Bangkok, Thailand. Procedia - Social and Behavioral Sciences, 195, 423-428. doi:10.1016/j.sbspro.2015.06.484.

[31] Harmon, K. (2010) How Does a Heat Wave Affect the Human Body? Scientific American, July 23, 2010.

[32] Canadian Centre for Occupational Health and Safety (CCOHS) (2019): Hot Environments - Health Effects and First Aid. Available online: https://www.ccohs.ca/oshanswers/phys_agents/heat_health.html (accessed on May 2019).

[33] Crimmins, A., Balbus, J., Gamble, J. L., Beard, C. B., Bell, J. E., Dodgen, D., Eisen, R. J., Fann, N., Hawkins, M., Herring, S. C., Jantarasami, L., Mills, D. M., Saha, S., Sarofim, M. C., Trtanj, J., \& Ziska, L. (2016). The Impacts of Climate Change on Human Health in the United States: A Scientific Assessment. In U.S. Global Change Research Program. U.S. Global Change Research Program. doi:10.7030/JOMG7MDX.

[34] Zhou, B., Rybski, D., \& Kropp, J. P. (2017). The role of city size and urban form in the surface urban heat island. Scientific Reports, 7(1). doi:10.1038/s41598-017-04242-2.

[35] Liu, S., Su, H., Zhang, R., Tian, J., \& Wang, W. (2016). Estimating the Surface Air Temperature by Remote Sensing in Northwest China Using an Improved Advection-Energy Balance for Air Temperature Model. Advances in Meteorology, 2016, 11. doi:10.1155/2016/4294219.

[36] Ingold, T. (2000). The perceptionofthe environment: Essays onlivelihood, dwellingand skill. London: Routledge. Ireland, P. (2008). Comparing responses to ethnic segregation in urban Europe. Urban Studies, 45(7), 1333.

[37] Danielson, S. (2015). Overview of Human Geography: Environmental Perception. Department of Geography, Geology, and the Environment. Slippery Rock University of Pennsylvania, Pennsylvania, United States.

[38] United Nations Educational, Scientific and Cultural Organization (UNESCO) (1977) Intergovernmental Programme on Man and the Biosphere (MAB), Project 13 ("Perception of environmental quality"). United Nations Educational, Scientific and Cultural Organization, 7 Place de Fontenot, 75700 Paris, France.

[39] E. Ite, A., J. Ibok, U., U. Ite, M., \& W. Petters, S. (2013). Petroleum Exploration and Production: Past and Present Environmental Issues in the Nigeria's Niger Delta. American Journal of Environmental Protection, 1(4), 78-90. doi:10.12691/env-1-4-2.

[40] Commission Niger Delta Development Master Plan (2006). The Popular Version; Adapted from the main Niger Delta Development Master Plan (NDRDMP) document by South-Sea Datcomm Limited, Abuja, Nigeria

[41] Ayoade, J. O (2004) Introduction to climatology for the tropics. In Indiana University Press; Spectrum books, Lagos, Nigeria.

[42] Adejuwon, Joseph O. (2012). Rainfall seasonality in the Niger Delta Belt, Nigeria. Journal of Geography and Regional Planning, 5(2). doi:10.5897/jgrp11.096.

[43] Yamane, T. (1967). Statistics, an Introductory Analysis, 2nd ed., Harper and Row, New York. United States.

[44] Nigerian Meteorological Agency (NIMET) (2021). “2021 Seasonal Rainfall Prediction (SCP)”. Available online: https://fscluster.org/sites/default/files/documents/2021_seasonal_climate_prediction_0.pdf (accessed on April 2021).

[45] Organsation for Economic Co-operation and Development (OECD). (2008) Household Behaviour and the Environment: Reviewing the Evidence. Available online: https://www.oecd.org/environment/consumption-innovation/42183878.pdf (accessed on April 2021). 